九州大学学術情報リポジトリ

Kyushu University Institutional Repository

Impacts of Three Silvicultural Prescriptions on Sediment Mobility and Water Quality in Headwater Streams of Forested Watersheds in the Upper Gulf Coastal Plain of Mississippi, USA

Choi, Byoung-Koo

Department of Forest Resources, College of Industrial Sciences, Kongju National University

Hatten, J. A.

Department of Forest Engineering, Resources \& Management, Oregon State University

Dewey, J. C.

Department of Geology and Geophysics, University of Wyoming

Ezell, A. W.

Department of Forestry, Mississippi State University

他

https://doi.org/10.5109/1434411

出版情報：九州大学大学院農学研究院紀要. 59 (1)，pp. 191-203，2014-02-28. Faculty of Agriculture, Kyushu University

バージョン :

権利関係 : 


\title{
Impacts of Three Silvicultural Prescriptions on Sediment Mobility and Water Quality in Headwater Streams of Forested Watersheds in the Upper Gulf Coastal Plain of Mississippi, USA
}

\author{
Byoung-Koo CHOI ${ }^{1 *}$, J. A. HATTEN ${ }^{2}$, J. C. DEWEY ${ }^{3}$, \\ A. W. EZELL ${ }^{4}$ and Kyoichi OTSUKI ${ }^{5}$ \\ Laboratory of Ecohydrology, Division of Forest Environmental Sciences, \\ Department of Agro-environmental Sciences, Faculty of Agriculture, \\ Kyushu University, Sasaguri, Fukuoka 811-2415, Japan \\ (Received October 31, 2013 and accepted November 11, 2013)
}

\begin{abstract}
Headwater streams are very important contributors of water, sediment, and nutrients to the downstream fluvial environment because their source areas compose more than $50-80 \%$ of a catchment. We investigated the influence of headwater areas (ephemeral and intermittent) on sediment mobility and downstream water quality using selected water quality parameters (temperature, dissolved oxygen, conductivity, and $\mathrm{pH}$ ) within three first-order catchments in the Upper Gulf Coastal Plain of Mississippi, USA. This study included one year of pre-harvest and two years of post-harvest observations for ephemeral-intermittent streams. Four treatments including two Best Management Practices (BMPs) for ephemeral streams were applied: standard BMP (SBMP) - removal of all merchantable stems while leaving understory intact with minimum surface soil disturbance; modified BMP (MBMP) - same as SBMP with the addition of logging debris to the drainage channel; Clearcut (CC) - total harvest with no BMPs applied; Reference (REF) - left uncut as a control. Forest clearcutting in ephemeral-intermittent streams resulted in substantial impacts to net erosion/ deposition for both channel and hillslope positions and significantly increased total suspend sediment (TSS) within ephemeral-intermittent stream channels. There were no significant differences among BMPs and REF in net erosion/deposition and TSS. However, perennial stream water quality did not change significantly among treatments following harvest. Results imply that the impacts of timber harvesting were ameliorated by implementing two ephemeral-intermittent stream BMPs during harvesting activities. These findings support the use of either SBMP or MBMP for conserving ephemeral-intermittent streams. While the addition of logging debris in the channel of MBMP did not substantially reduce erosion and sediment flux when compared to SBMP, there may be operational benefits to permitting using a natural sediment baffle because it reduces operational constraints allowing for a greater timber yield.
\end{abstract}

Key words: best management practices, headwater, sediment, streamside management zones, timber harvesting

\section{INTRODUCTION}

Transitional boundaries between terrestrial and aquatic systems represent dynamic habitats which link ecosystem processes that influence the movement of organisms, nutrients, materials and energy throughout the river ecosystem (Naiman and Décamp, 1997). Disturbance of these areas through silvicultural practices may adversely affect these processes within an ecosystem at local and landscape levels.

There are no universally accepted definitions for headwater streams (Macdonald and Coe, 2007; Fritz et $a l ., 2008)$, but they are generally agreed to be a critical component of stream initiation processes and typically represent from 50 to $80 \%$ of the total stream length in

\footnotetext{
1 Department of Forest Management, College of Forest and Environmental Sciences, Kangwon National University, Korea

2 Department of Forest Engineering, Resources \& Management, Oregon State University, Corvallis, OR 97331, USA

3 Department of Geology and Geophysics, University of Wyoming, P.O. Box 3006, Laramie, WY 82071, USA

${ }^{4}$ Department of Forestry, Mississippi State University, Mississippi State, MS39762, USA

5 Kasuya Research Forest, Kyushu University, Sasaguri, Fukuoka 811-2415, Japan

* Corresponding author (E-mail: tokki4137@gmail.com)
}

the U.S. (Leopold et al., 1964; Hansen, 2001; Benda et al., 2005). Headwater streams are often considered to be the greatest nonpoint sources of sediment in natural conditions and are a crucial part of overall watershed dynamics (Doppelt et al., 1993; Meyer and Wallace, 2001; Gomi et al., 2002). Headwaters are also important sources for downstream food webs, local biodiversity, and riparian ecosystems. However, their actual functional role in the context of downstream water quality has not been well quantified and is not adequately considered in resource management (Gomi et al., 2002; Wipfli et al., 2007). Headwater streams begin where surface flow is sufficiently concentrated to cause scouring and formation of distinct channels and thus often contain ephemeral streams for short periods during and after storm events. There are indications that shallow subsurface flow in these ephemeral streams may occur for days or weeks post-precipitation events (especially under saturated soil conditions) and that a number of terrestrial and aquatic organisms may respond to this highly dynamic hydrologic flow (Muotka and Virtanen, 1995; Muys and Granval, 1997; Paoletti, 1999; Holland and Luff, 2000).

One of the major concerns associated with timber management activities during silvicultural operations such as harvesting and planting is soil disturbance, ero- 
sion and compaction as a result of installation of roads and trails and the use of equipment. Although sediment delivery to streams depends on the hydrologic connectivity between hillslopes and stream channels (Sidle et al., 2004; Gomi et al., 2006), increased sedimentation in streams may degrade water quality and habitat availability in stream ecosystems (Sun et al., 2001; HeartstillScalley and Aid, 2003). Sediment is considered to be the largest potential nonpoint source pollutant of the Southern U.S. (Grace, 2005) and negatively impact water quality by decreasing dissolved oxygen levels and altering aquatic habitat (Blackburn et al., 1990; Carroll et al., 2004). In response to water quality concerns in the U.S., individual states have developed guidelines known as best management practices (BMPs) for preventing or reducing nonpoint source pollution.

Silvicultural streamside management zones (SMZs), a typical forest management BMP, are designed to preserve riparian ecological functions by linking terrestrial and aquatic ecosystems, reducing logging-induced inputs to streams (e.g. sediment and woody debris), decreasing the volume and velocity of overland flow, and stabilizing stream banks and protecting streams from increased insolation as a result of canopy removal.

Most BMP studies in the Southeastern U.S. have focused on the use and effectiveness of SMZs as a forestry BMP to reduce nonpoint source pollution (Lynch et al., 1985; Ursic, 1991; Keim and Schoenholtz, 1999; Ice et al., 2003; Carroll et al., 2004; Rivenbark and Jackson, 2004; Vowell and Frydenborg, 2004). However, these studies have been mostly limited to the riparian zone of perennial and intermittent reaches of stream networks that have specific guidelines for their SMZs (Wenger, 1999; Blinn and Kilgore, 2001). In the case of the Upper Gulf coastal Plain of Mississippi, USA, there has been little or no documentation on the effects of silvicultural practices in ephemeral streams on downstream water quality.

Stream size and surface hydrology are important factors influencing natural wood accumulation in streams (Collier and Bowman, 2003). Woody debris management during or after harvest operations has a major bearing on volume of wood remaining in stream channels (Diez et al., 2001). Woody debris can alter flow velocity and direction and exert control over sediment and organic matter transport to downstream reaches (Woodsmith and Swanson, 1997). However, current management practices usually involve removal of logging debris from streams to reduce the risk of slash dam formation and transport of wood during high flow which may damage stream habitat and downstream infrastructures such as culverts and bridges (Collier and Bowman, 2003; Baillie et al., 2005). Moreover, the effects of within-channel logging debris on soil erosion and sediment mobility are not well understood.

This study examined the influence of headwater areas (ephemeral and intermittent) on sediment mobility and downstream water quality using selected water quality parameters (temperature, dissolved oxygen, conductivity, and $\mathrm{pH}$ ). We analyzed one year of pre-har- vest and two years of post-harvest observations for ephemeral-intermittent streams. The objectives of this study were to (1) examine the influence of three silvicultural prescriptions within ephemeral-intermittent streams on sediment mobility and downstream water quality and (2) test the effects of logging debris left in ephemeral intermittent channels on soil erosion and sediment mobility.

\section{METHODS}

\section{Site description}

The study area comprises three first-order headwater catchments located in Webster County within the Sand-Clay Hills subsection of the Hilly Coastal Plain Province of Mississippi, USA (Fig. 1). Study sites were chosen based on the presence of intermittent streams, forest land available for research, and similarity of vegetation, topography, and soils. We selected four subwatersheds containing ephemeral and intermittent streams within each catchment (Fig. 1). The study area has a humid subtropical climate characterized by long hot summers and short mild winters. Precipitation is well distributed throughout the year with a 30 year mean of 1,451 mm. Short- and high-intensity storms are common and storm precipitation can exceed $100 \mathrm{~mm}$ per day. Mean winter temperature is $7^{\circ} \mathrm{C}$; mean summer temperature is $26^{\circ} \mathrm{C}$ (U.S. National Weather Service station 222896 Eupora, MS). Watershed size ranged from 1.8 to 7.1 ha among the 12 watersheds. Stream and hillslope gradients ranged from 2 to $19 \%$ and 2 to $26 \%$, respectively, but both were generally consistent within catchments (Table 1). Soils within the rolling to ruggedly hilly area are high in clay content with A-horizons of either loam or silt loam. The hillslope water table typically drops to $>2 \mathrm{~m}$ below the surface in the summer (Choi, 2011).

Two named soils are present (McMullen \& Ford 1978): (1) well to moderately well drained Sweatman United States Department of Agriculture (USDA) taxonomy = Fine, mixed, semiactive, thermic Typic Hapludults - World Reference Base (WRB) taxonomy = Profondic Alisol); and (2) Providence - USDA taxonomy = Finesilty, mixed, active, thermic Oxyaquic Fragiudalfs WRB taxonomy = Albic Lixisols. Study sites are in the Southeastern Mixed Forest Province (Bailey, 1983). Overstory vegetation is loblolly pine (Pinus taeda L.) of similar age with a smaller component of mixed hardwoods. Common hardwood species are yellow poplar (Liriodendron tulipifera L.), sweetgum (Liquidambar styraciflua L.), eastern hophornbeam (Ostrya virginiana (Mill.) K. Koch), American beech (Fagus grandifolia Ehrh.), black cherry (Prunus serotina Ehrh.), oak species (Quercus spp.), and hickory species (Carya spp.).

\section{Study design and treatment}

Twelve similar first-order watersheds with intermittent streams were selected for study and arranged in a completely randomized block design (RCB) which 


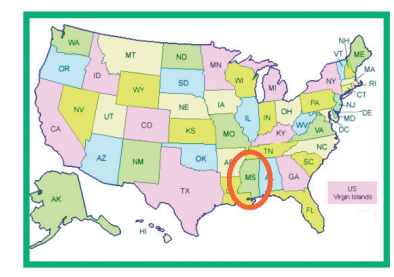

Ingram

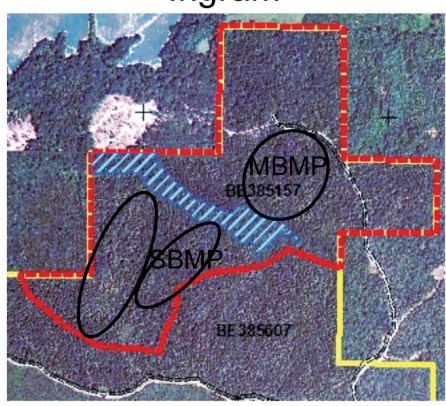

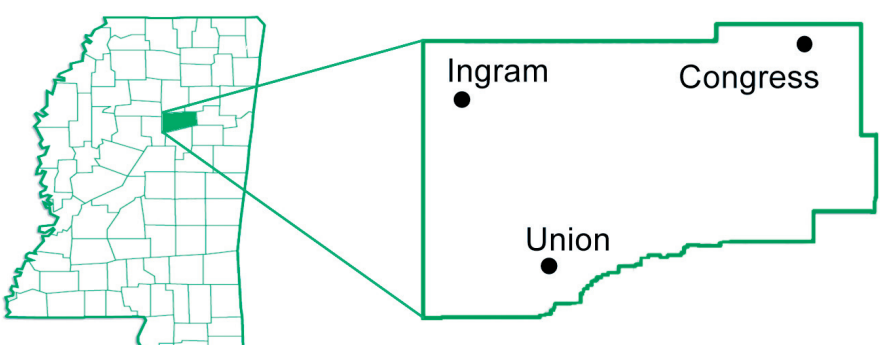

Union
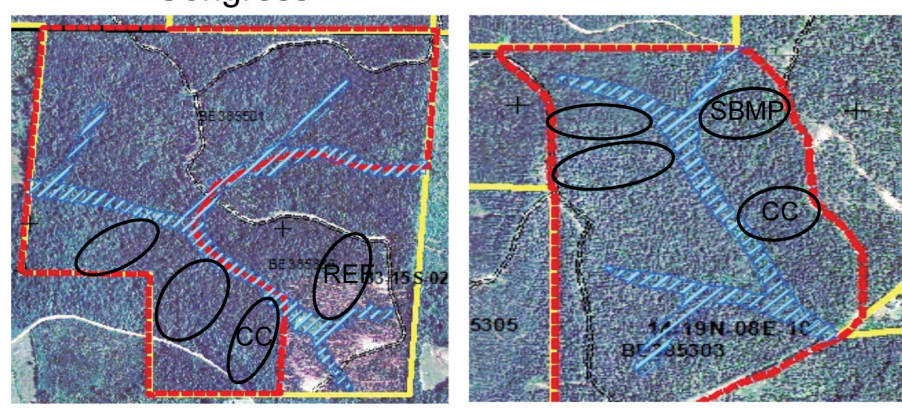

Fig. 1. Location of study watersheds of Webster County, Mississippi. Each treatment boundary does not reflect its actual size. Red dashed lines indicate harvest boundaries for each study watershed.

Table 1. Physical characteristics, pre- and post-harvest basal area of the study watersheds in the Upper Gulf Coastal Plain, Webster County, Mississippi

\begin{tabular}{|c|c|c|c|c|c|c|c|}
\hline Watershed & Treatment & $\begin{array}{l}\text { Watershed } \\
\text { area } \\
\text { (ha) }\end{array}$ & $\begin{array}{l}\text { Stream } \\
\text { length } \\
(\mathrm{m})^{3}\end{array}$ & $\begin{array}{c}\text { Stream gradient } \\
(\%) \\
\text { Mean }(\min , \max )^{\mathrm{b}}\end{array}$ & $\begin{array}{c}\text { Hillslope gradient } \\
\text { (\%) } \\
\text { Mean (min, max) }\end{array}$ & $\begin{array}{c}\text { pre-harvest } \\
\text { basal area } \\
\left(\mathrm{m}^{2} / \mathrm{ha}\right)^{c}\end{array}$ & $\begin{array}{c}\text { post-harvest } \\
\text { basal area } \\
\left(\mathrm{m}^{2} / \mathrm{ha}\right)^{\mathrm{c}}\end{array}$ \\
\hline Union & SBMP & 3.8 & 92 & $5(4,6)$ & $26(13,39)$ & 16.2 & 14.5 \\
\hline Union & MBMP & 3.6 & 83 & $4(3,5)$ & $22(3,42)$ & 11.3 & 7.8 \\
\hline Union & $\mathrm{CC}$ & 1.8 & 81 & $4(3,5)$ & $26(14,40)$ & 10.7 & 3.2 \\
\hline \multirow[t]{2}{*}{ Union } & REF & 2.4 & 78 & $5(4,5)$ & $21(3,39)$ & 15.1 & 15.1 \\
\hline & & & & & & 14.5 & \\
\hline Congress & SBMP & 2.4 & 117 & $5(4,5)$ & $15(2,29)$ & 14.5 & 10.4 \\
\hline Congress & MBMP & 2.9 & 96 & $13(6,19)$ & $14(3,31)$ & 11.7 & 5.5 \\
\hline Congress & $\mathrm{CC}$ & 2.5 & 95 & $19(12,22)$ & $18(12,30)$ & 12.7 & 1.5 \\
\hline Congress & $\mathrm{REF}$ & 2.1 & 102 & $12(11,13)$ & $18(10,40)$ & 11.2 & 11.2 \\
\hline lngram & SBMP & 3.3 & 73 & $3(2,4)$ & $19(16,24)$ & 10.8 & 4.8 \\
\hline lngram & MBMP & 6.7 & 55 & $2(2,3)$ & $2(2,3)$ & 12.3 & 3.1 \\
\hline lngram & $\mathrm{CC}$ & 7.1 & 85 & $5(4,6)$ & $16(10,22)$ & 18.3 & 0.9 \\
\hline lngram & $\mathrm{REF}$ & 6.3 & 116 & $5(4,6)$ & $20(5,29)$ & 16.9 & 16.9 \\
\hline
\end{tabular}

${ }^{a}$ Stream length was a distance from the channel location of the first erosion/deposition measurement transect to the channel location of 5th erosion/deposition measurement transect.

${ }^{\mathrm{b}}$ Stream gradient was measured within erosion/deposition measurement transects.

${ }^{\mathrm{c}}$ Values are approximate based on subsample within erosion/deposition measurement transects. 
consisted of three blocks of four randomly assigned treatments. The uppermost reaches (ephemeral streams) not governed by Mississippi's Forestry BMP guidelines (Mississippi Forestry Commission, 2000) received one of the following treatments: (1) Clearcut (CC) - total harvest with no BMPs applied within the drainage channels; (2) standard BMP (SBMP) - removal of all merchantable stems greater than $15.2 \mathrm{~cm} \mathrm{DBH}$ and $20.3 \mathrm{~cm}$ diameter at the base of the butt log leaving understory intact with minimum surface soil and forest floor disturbance. Logging debris was prohibited in the drainage channel; (3) modified BMP (MBMP) - same as SBMP with the addition of logging debris to the ephemeral drainage channel in an attempt to decrease energy in the system and minimize head-cutting and continued channel development; (4) Reference (REF) left uncut as a control. Since SMZs along the perennial stream were maintained these treatments, including the clearcut, was carried out in accordance with Mississippi's Forestry BMP guidelines. Treatment boundaries were delineated using watershed contours in September 2007. Timber harvesting was conducted using rubber tired feller-bunchers and grapple skidders during October - December 2007, while surface soil conditions were dry. Commercial timber harvesting was carried out in accordance with Mississippi's Forestry BMP guidelines; the only exception was MBMP in which logging debris was left in ephemeral drainage channels to reduce flow energy and provide a sediment baffle. Following harvest, basal area removed ranged from $1.7 \mathrm{~m}^{2} /$ ha in $\mathrm{SBMP}$ to $17.4 \mathrm{~m}^{2} /$ ha (Table 1 ). Percent removal by treatment was: CC 70-95\%; SBMP 10-50\%; MBMP 31-75\%; REF 0\%.

\section{Data collection}

\section{Soil erosion/deposition}

At the head of each intermittent stream, five transects were established perpendicular to the developed channel from the top of the ephemeral streams through the entire length of the intermittent stream (Fig. 2). Spacing between transects was dependent on the length of the stream as well as the areal extent of the watershed and ranged from 12 to $30 \mathrm{~m}$. Each transect contained five wells constructed of $5 \mathrm{~cm}$ i.d. polyvinyl chloride pipe at a within-transect spacing of $5 \mathrm{~m}$; these wells were used as erosion/deposition measurement points resulting in 25 erosion/deposition measurement points per treatment and 300 measurement points across the study area (Fig. 2). After well installation, the height of the pipe above soil surface was measured and served as a datum for subsequent measurements; initial height above surface soil ranged 55 to $70 \mathrm{~cm}$. A vertical line was permanently marked on each well to ensure successive measurements were taken at precisely the same location. Erosion/deposition was monitored over 32 months (February 2007 to August 2009) with three pre-harvest measurements (February, August, and October through December 2007) and four postharvest measurements [March 2008 (T1), September 2008 (T2), February 2009 (T3), and August 2009 (T4)].

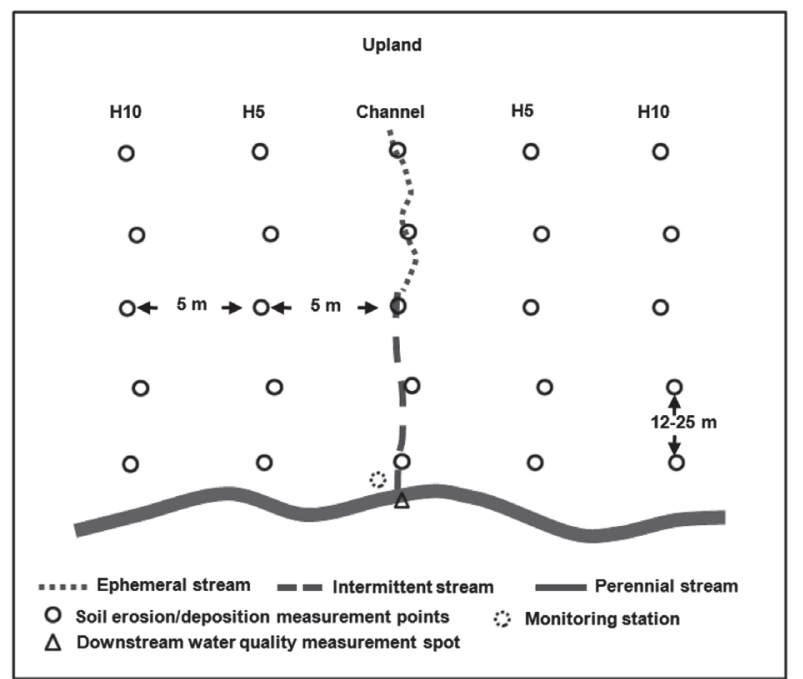

Fig. 2. Schematic of field sampling design in study watersheds of Webster County, Mississippi. Each transect consisted of 5 erosion measurement points. Twenty-five erosion measurement points were installed per treatment. Each point was located at $5 \mathrm{~m}$ intervals along each transact. Transect spacing ranged from 12 to $25 \mathrm{~m}$, dependent upon the length and slope of the stream as well as the areal extent of the watershed. H5 and H10 indicate $5 \mathrm{~m}$ and $10 \mathrm{~m}$ erosion measurement positions from channel center, respectively.

\section{Stream water sampling}

Streamflow and total suspended sediment (TSS) concentrations within ephemeral-intermittent streams were monitored for 30 months (March 2007 to August 2009) during the rising limb of major precipitation events. Within each intermittent flow segment above the confluence with the downstream perennial stream, a $1.8 \mathrm{~m}$ length of $25.4 \mathrm{~cm}$ i.d. schedule 40 polyvinyl chloride pipe was installed and stabilized with sandbags to constrain flow. Level and flow within the pipe were directly measured with area velocity sensors and flow loggers (ISCO 4150 area velocity flow logger, ISCO Inc., Lincoln, NE) which recorded at 15-minute intervals. Automatic composite samplers (ISCO GLS water sampler, ISCO Inc., Lincoln, NE) were linked to flow loggers and programmed to begin sample collection when flow depth was greater than 20 to $50 \mathrm{~mm}$ depending on season and flow. Upon initiation of sampling, samplers were programmed to collect $200 \mathrm{ml}$ of water every $30 \mathrm{~min}$ utes up to 20 samples per event; samples were reserved in a composite bottle. At the end of each precipitation event, a well-stirred subsample of $500 \mathrm{ml}$ was removed from the composite sample and analyzed for TSS in the laboratory using standard methods (APHA, 1987). Due to variability in event-flow, streams were not sampled simultaneously and the number of sampled storm events differed among streams.

Perennial stream water quality was monitored monthly (March 2007 to December 2009) at locations immediately downstream of the confluence between intermittent streams of treatment watersheds and the perennial stream. In-situ measurements of tempera- 
ture, $\mathrm{pH}$, dissolved oxygen (DO), and conductivity were conducted using a portable multiparameter sensor (YSI 556 MPS meter, YSI Incorporated, Yellow Springs, OH). Sensors were calibrated the morning of sampling and proper calibration was verified upon return from the field. All four watersheds in each catchment were visited consecutively, and catchments were visited in the same order every time to reduce effects of diurnal fluctuations in analysis (Keim and Schoenholtz, 1999).

\section{Data analysis}

Four consecutive post-harvest time periods (designated T1 to T4) were used to correlate post-harvest erosion/deposition and changes in TSS concentration. For the purpose of characterizing erosion/deposition, we categorized erosion/deposition measurement locations within each transect as channel, 5 m from channel (H5), and $10 \mathrm{~m}$ from channel (H10). Three classes consisting of 25 erosion/deposition measurement points (five channels, ten H5, and ten H10) for each treatment were considered for data analysis (Fig. 2). Overall post-harvest net erosion/deposition by position (channel, H5, and H10) within treatments was calculated by subtracting measurements for $\mathrm{T} 1$ from those of $\mathrm{T} 4$, while for each post-harvest period we calculated net erosion/deposition by position within treatments by subtracting measurements from the previous period. We also examined each post-harvest treatment response in net erosion/ deposition by position and associated precipitation characteristics (total precipitation, daily maximum precipitation, and maximum 30-minute intensity). Pearson correlation analysis was used to determine whether there existed linear relationships between precipitation characteristics (e.g. total precipitation, daily maximum precipitation, maximum 30-minute intensity) and net erosion/deposition by position within treatments for each post-harvest period. For TSS analysis, storm precipitation during each sampled event was calculated by treatment and the relationship between TSS and storm precipitation was examined using a simple regression analysis for each post-harvest period (T1 to T4).

We evaluated the effects of timber harvesting on sediment mobility and downstream water quality and compared the resultant hydrologic responses among treatments. For erosion/deposition analysis, we employed the following model (Eq. (1)). Pre-harvest value was a covariate for erosion/deposition analysis.

$$
\begin{aligned}
& Y_{i j k}=\mu+b l k_{i}+t r t_{i j}+p s n_{k}+t r t_{i j} \times p s n_{k}+\varepsilon_{i j k} \\
& (i=1, \ldots, 4 ; j=1, \ldots, 4 ; k=1, \ldots, 3)
\end{aligned}
$$

where:

$Y_{i j k}$ is the mean net erosion/deposition for position $k$ in treatment $j$ in block $i$.

$\mu$ is the grand mean.

$b l k_{i}$ is the random effect for block $i$.

$\operatorname{trt}_{i j}$ is the fixed effect for treatment $j$ in block $i$.

$p s n_{k}$ is a fixed factor for position $k$, where 1,2 , and 3 represent channel, $\mathrm{H} 5$, and $\mathrm{H} 10$, respectively, in treatment $j$ in block $i$.

$\varepsilon_{i j k}$ is the random error for position $k$ in treatment $j$ in block $i$.

For downstream water quality analysis, we separated water quality data in two groups: summer months (June to September) and non-summer months (October to May) and examined treatment means across both time periods for all analyses (Eq. (2)).

$$
\begin{aligned}
& Y_{i j k}=\mu+b l k_{i}+t r t_{i j}+t_{k}+\operatorname{trt}_{i j} \times t_{k}+\varepsilon_{i j k} \\
& (i=1, \ldots, 4 ; j=1, \ldots, 4 ; k=1 \text { or } 2)
\end{aligned}
$$

where:

$Y_{i j k}$ is the mean $\mathrm{pH}$, temperature, conductivity, or DO concentration for treatment $j$ in block $i$ at time $k$.

$\mu$ is the grand mean.

$b l k_{i}$ is the random effect for block $i$.

$t_{r} t_{i j}$ is the fixed effect for treatment $j$ in block $i$.

$t_{k}$ is a fixed factor for time $k$, where 1 and 2 represent summer months and non-summer months, respectively.

$\varepsilon_{i j k}$ is the random error for treatment $j$ in block $i$ at time $k$.

Pre-harvest value was a covariate for water quality analysis. We used the MIXED procedure of SAS (SAS Institute Inc., 2008) for all analyses. When main effects or interactions were significant, least square means were computed and comparisons were made using a significance level of $\alpha=0.05$ and Tukey's HSD test for all analyses.

\section{RESULTS}

\section{Precipitation}

This study encompassed three years (one pre-harvest and two post-harvest) with three distinct precipitation patterns for the calendar years of the entire study period. Total precipitation for 2007 (pre-harvest) was below-average at 1,001 mm (30-year mean=1,451 mm). Total precipitation for 2008 ( $1^{\text {st }}$ year post-harvest) was roughly equal to the 30 -year mean at $1,498 \mathrm{~mm}$. However, 28\% of the total precipitation for 2008 fell during the months of August and December (Fig. 3). The net result was that the study watersheds experienced a severe regional drought from February 2007 through December 2008 (National Drought Mitigation Center 2008). Total precipitation for 2009 ( $2^{\text {nd }}$ year post-harvest) was 2,194 $\mathrm{mm}$, the highest in the 25-year record for Webster County, Mississippi.

\section{Soil erosion/deposition}

Prior to harvest, net erosion/deposition was not different among treatments $(p=0.781)$ nor was it significantly different from zero in all positions; channel $(p=0.116), \mathrm{H} 5(p=0.252)$ and H10 $(p=0.201)$. Twentytwo months post-harvest, net erosion ranged from $0.30-1.08 \mathrm{~cm}$ in harvested treatments (CC, SBMP and MBMP) while net deposition of $0.14 \mathrm{~cm}$ occurred in REF. Post-harvest net erosion/deposition differed significantly among treatments $(p=0.002)$. Net erosion/ 
deposition was $1.08 \pm 0.42 \mathrm{~cm}(95 \% \mathrm{CI})$ in $\mathrm{CC}$, followed by $0.52 \pm 0.55 \mathrm{~cm}(95 \% \mathrm{CI})$ in MBMP, $0.30 \pm 0.44 \mathrm{~cm}(95 \%$ $\mathrm{CI}$ ) in SBMP, and $0.14 \pm 0.44 \mathrm{~cm}(95 \% \mathrm{CI})$ in REF (Fig. 4).
Hillslope positions in all treatments exhibited net erosion ranging from 0.47 to $2.24 \mathrm{~cm}$ overall, 22 months post-harvest (T1 to T4); channel positions exhibited variable responses by treatment (Fig. 5). Significant

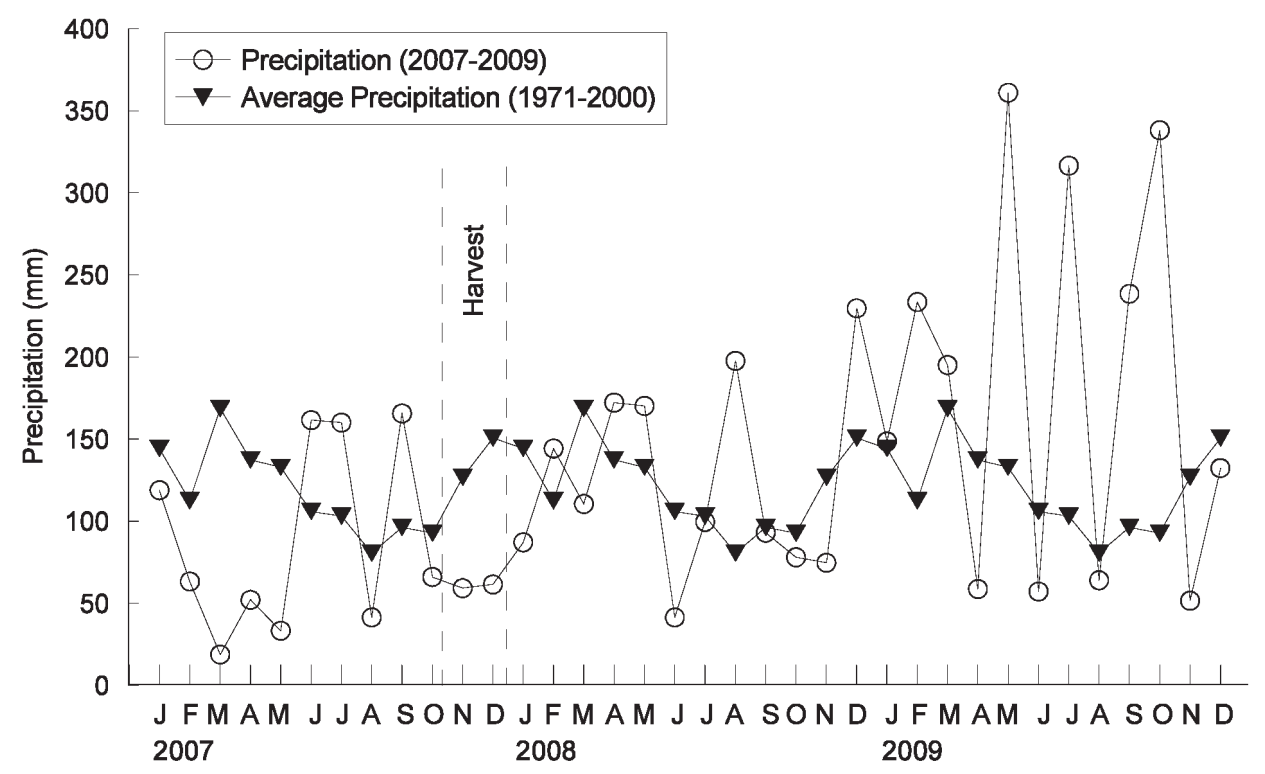

Fig. 3. Precipitation from Jan. 2007 through Dec. 2009 and 30 year mean precipitation (1971-2000) for Webster County, Mississippi.

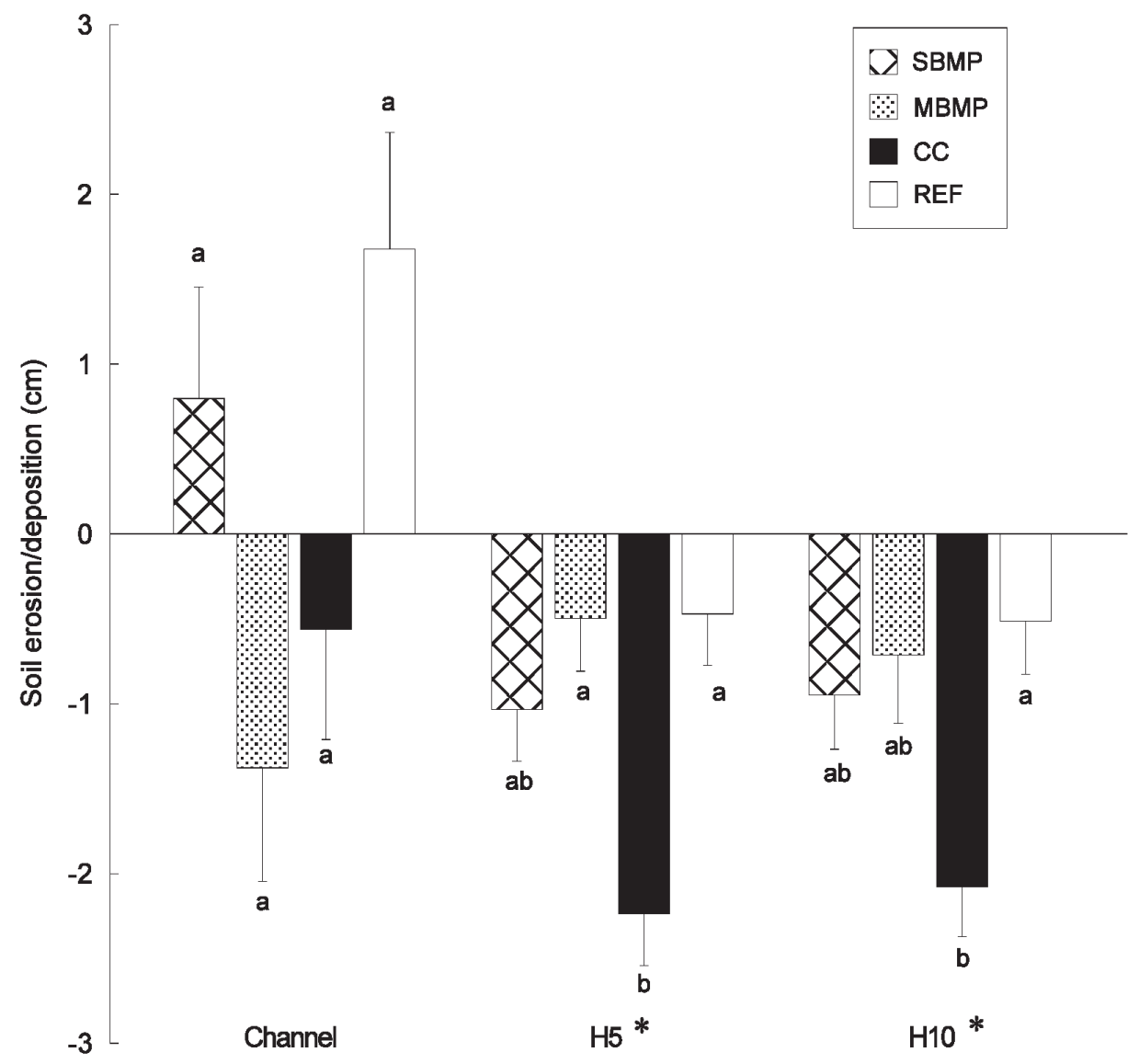

Fig. 4. Differences in net soil erosion/deposition by treatment 22 months post-harvest in small headwater streams of Webster County, Mississippi. Means with different letters indicate significant differences at $\alpha=0.05$ within a position. Negative values indicate soil erosion and positive values indicate soil deposition. * indicates significant difference at $\alpha=0.05$ among treatments. H5 and H10 indicate $5 \mathrm{~m}$ and $10 \mathrm{~m}$ erosion measurement positions from channel center, respectively. 
differences in net soil erosion/deposition 22 months post-harvest were detected in hillslope positions ( $\mathrm{H} 5$, $p=0.017$ and H10, $p=0.044$ ), but not in the channel position $(p=0.083)$. Significant effects in hillslope positions occurred mainly between CC and REF.

Immediately following harvest (T1), there were significant differences in net erosion/deposition among treatments, and there were discernible patterns in net erosion/deposition by topographic position. During this period, erosion was a dominant process in hillslope positions whereas all channel positions exhibited net deposition regardless of treatment (Fig. 5). Net erosion was highest in CC $(0.98-1.21 \mathrm{~cm})$, followed by SBMP $(0.65-$ $0.79 \mathrm{~cm})$, REF $(0.3-0.35 \mathrm{~cm})$, and MBMP $(0.2-0.02 \mathrm{~cm})$. Post-harvest T2 and T3, net erosion/deposition in hillslope positions decreased drastically. Net erosion/deposition in channel positions, however, was highly variable during this period and this pattern continued to T4. Since post-harvest T4 was the wettest period with frequent high-magnitude precipitation events, there was considerable net soil erosion in hillslope positions across all treatments; CC $(0.83-0.86 \mathrm{~cm}), \operatorname{SBMP}(0.33-0.34 \mathrm{~cm})$, REF (0.22-0.30 cm), and MBMP (0.2-0.30 cm) (Fig. 5).

There was no clear relationship between net erosion/ deposition and precipitation characteristics in channel positions (Table 2). Hillslope positions, however, had a positive linear relationship between net erosion/deposition and maximum 30-minute intensity in all cases except MBMP, H10.

\section{Storm TSS}

Due to regional extreme drought conditions, we collected only twelve water samples from three storm events for TSS analysis prior to harvest. There was no significant difference $(p=0.149)$ in pre-harvest TSS among treatments; mean TSS concentrations were $283.9 \mathrm{mg} / \mathrm{L}$ (SE: 75.4 in SBMP), $263.7 \mathrm{mg} / \mathrm{L}$ (SE: 85.2 in MBMP), $214.7 \mathrm{mg} / \mathrm{L}$ (SE: 72.3 in CC), and $166.4 \mathrm{mg} / \mathrm{L}$ (SE: 92.5 in REF).

Post-harvest (T1 to T4), there was no difference in the regression intercept among treatments for all periods with the exception of post-harvest T3 at the signifi-

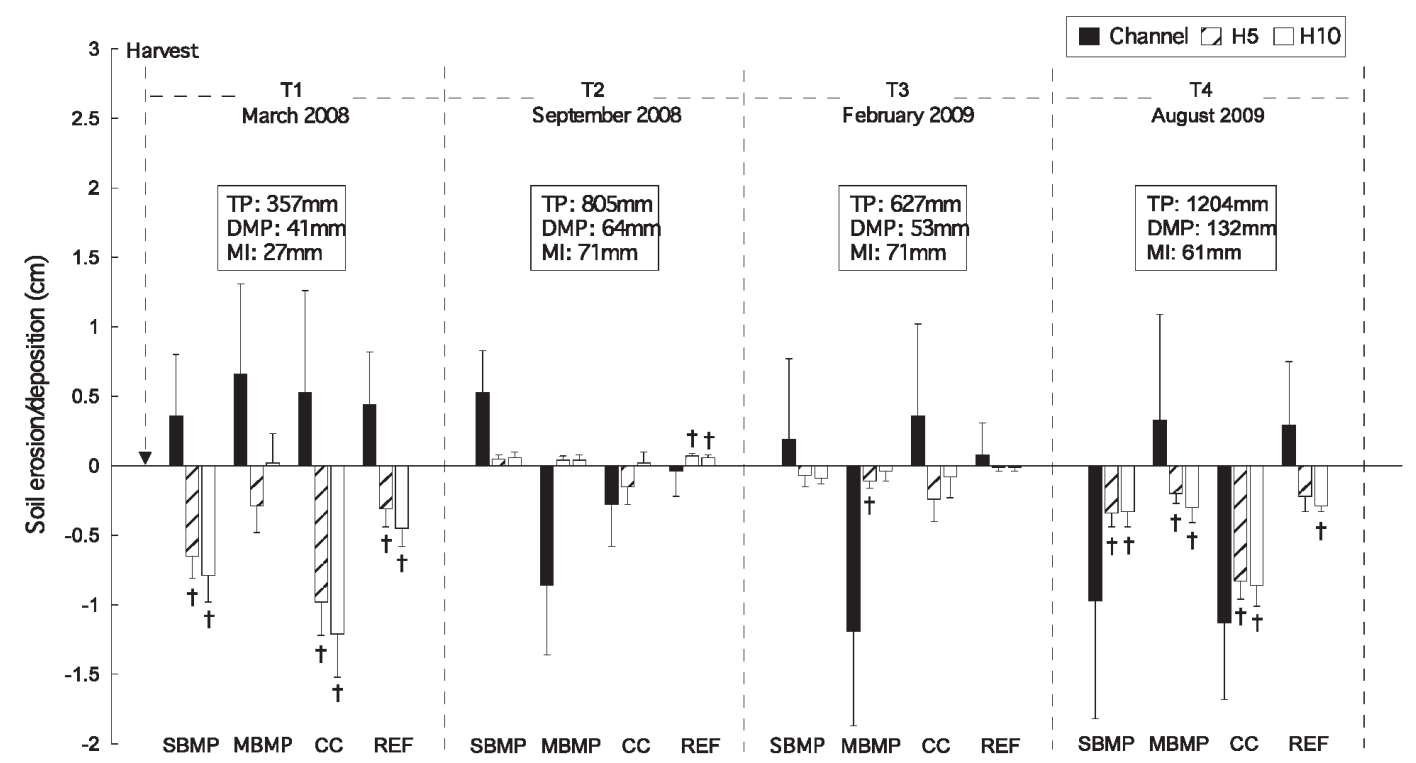

Fig. 5. Changes in net soil erosion/deposition by position, treatment and precipitation characteristics over 4 postharvest time periods in small headwater streams of Webster County, Mississippi. TP, DMP, and MI represent total precipitation, daily maximum precipitation, and maximum 30-minute intensity, respectively. $†$ indicates significant differences from zero at $\alpha=0.05$. Negative values indicate soil erosion and positive values indicate soil deposition.

Table 2. Relationships between net soil erosion/deposition and precipitation characteristics in small headwater streams of Webster County, Mississippi

\begin{tabular}{|c|c|c|c|c|c|c|c|c|c|}
\hline \multirow{2}{*}{ Treatment } & \multicolumn{3}{|c|}{ Channel } & \multicolumn{3}{|c|}{ H5 } & \multicolumn{3}{|c|}{ H10 } \\
\hline & $\mathrm{TP}$ & DMP & MI & $\mathrm{TP}$ & DMP & MI & $\mathrm{TP}$ & DMP & MI \\
\hline SBMP & $-0.47^{*}$ & $-0.51 *$ & -0.10 & 0.28 & 0.02 & $0.82 *$ & 0.43 & 0.13 & $0.96 *$ \\
\hline MBMP & 0.03 & 0.18 & -0.45 & 0.15 & -0.06 & $0.60^{*}$ & -0.40 & -0.49 & 0.01 \\
\hline $\mathrm{CC}$ & $-0.56^{*}$ & $-0.53^{*}$ & -0.26 & 0.01 & -0.19 & $0.55^{*}$ & 0.10 & -0.15 & $0.71 *$ \\
\hline $\mathrm{REF}$ & -0.19 & 0.05 & $-0.61 *$ & 0.15 & -0.10 & $0.65^{*}$ & 0.23 & -0.10 & $0.90 *$ \\
\hline
\end{tabular}

* indicates significant in coefficient values at $\alpha=0.05$.

TP, DMP, and MI represent total precipitation, daily maximum precipitation, and maximum 30-minute intensity, respectively. 
cance level of $\alpha=0.05$ (Fig. 6). However, there were differences in mean TSS among treatments overall (T1 to T4) indicating differences in the regression slope at a significance level of $\alpha=0.05$ (Fig. 6a); the most significant increase occurred in CC (452.9 mg/L) followed by $242.9 \mathrm{mg} / \mathrm{L}$ in MBMP, $226.3 \mathrm{mg} / \mathrm{L}$ SBMP and $200.5 \mathrm{mg} / \mathrm{L}$ in REF. Significant linear relationships existed between TSS and storm precipitation during this period in all treatments except REF: CC $\left(r^{2}=0.58 ; p<0.001\right)$, MBMP $\left(r^{2}=0.47 ; p<0.001\right), \operatorname{SBMP}\left(r^{2}=0.43 ; p<0.001\right)$, and REF $\left(r^{2}=0.14 ; p=0.19\right)$ (Fig. 6a). Due to prolonged drought conditions and difficulties with field equipment, TSS data were not available for post-harvest $\mathrm{T} 1$ which would be expected to have had the highest TSS. During post-harvest T2, CC had the highest mean TSS among treatments, and two BMPs (SBMP and MBMP) tended to have slightly higher mean TSS than REF. There were no significant differences between SBMP, MBMP, and REF in mean TSS (Fig. 6b). Similar trends observed during post-harvest T3, however, there were no significant differences between treatments in mean TSS (Fig. 6c). During post-harvest T4, when compared to T2 and T3, mean TSS increased in all treatments with the exception of REF and there were significant differences between CC and other treatments: $566.8 \mathrm{mg} / \mathrm{L}$ (CC),
$325.6 \mathrm{mg} / \mathrm{L} \quad$ (SBMP), $304.5 \mathrm{mg} / \mathrm{L} \quad$ (MBMP), and $189.8 \mathrm{mg} / \mathrm{L}$ (REF). Post-harvest increases in TSS were primarily due to the increased magnitude and frequency of intense storm events (Fig. 6d). There was a significant linear relationship between TSS and storm precipitation in all treatments, except REF: CC $\left(r^{2}=0.78\right.$; $p<0.001)$, SBMP $\left(r^{2}=0.76 ; p<0.001\right), \operatorname{MBMP}\left(r^{2}=0.50\right.$; $p<0.011)$, and REF $\left(r^{2}=0.26 ; p=0.331\right)$.

\section{Downstream water quality}

During the summer of 2007 and 2008, there was little to no stream flow in the perennial streams and most water quality parameters exhibited large variability (Fig. 7). Prior to harvest, there were significant differences in conductivity ( $p=0.001), \mathrm{pH}(p=0.011)$, and DO $(p=0.001)$ among treatments during the summer months; mean conductivity in MBMP $(156 \mu \mathrm{S} / \mathrm{cm}, \mathrm{SE}$ : 51.2) was different from all other treatments $(76.7 \mu \mathrm{S} /$ cm, SE: 15.2 in SBMP; $65.3 \mu \mathrm{S} / \mathrm{cm}, \mathrm{SE}: 12.6$ in $\mathrm{CC}$; $76.1 \mu \mathrm{S} / \mathrm{cm}, \mathrm{SE}: 13.3$ in REF); mean $\mathrm{pH}$ in MBMP (6.14, SE: 0.14) and CC (6.24, SE: 0.15) was similar, but different from SBMP (6.49, SE: 0.03) and REF (6.58, SE: $0.04)$; mean DO in MBMP (3.23 mg/L, SE: 0.46) and CC (3.11 mg/L, SE: 0.51) was similar, but different from REF (4.13 mg/L, SE: 0.39) and SBMP (4.48 mg/L, SE:
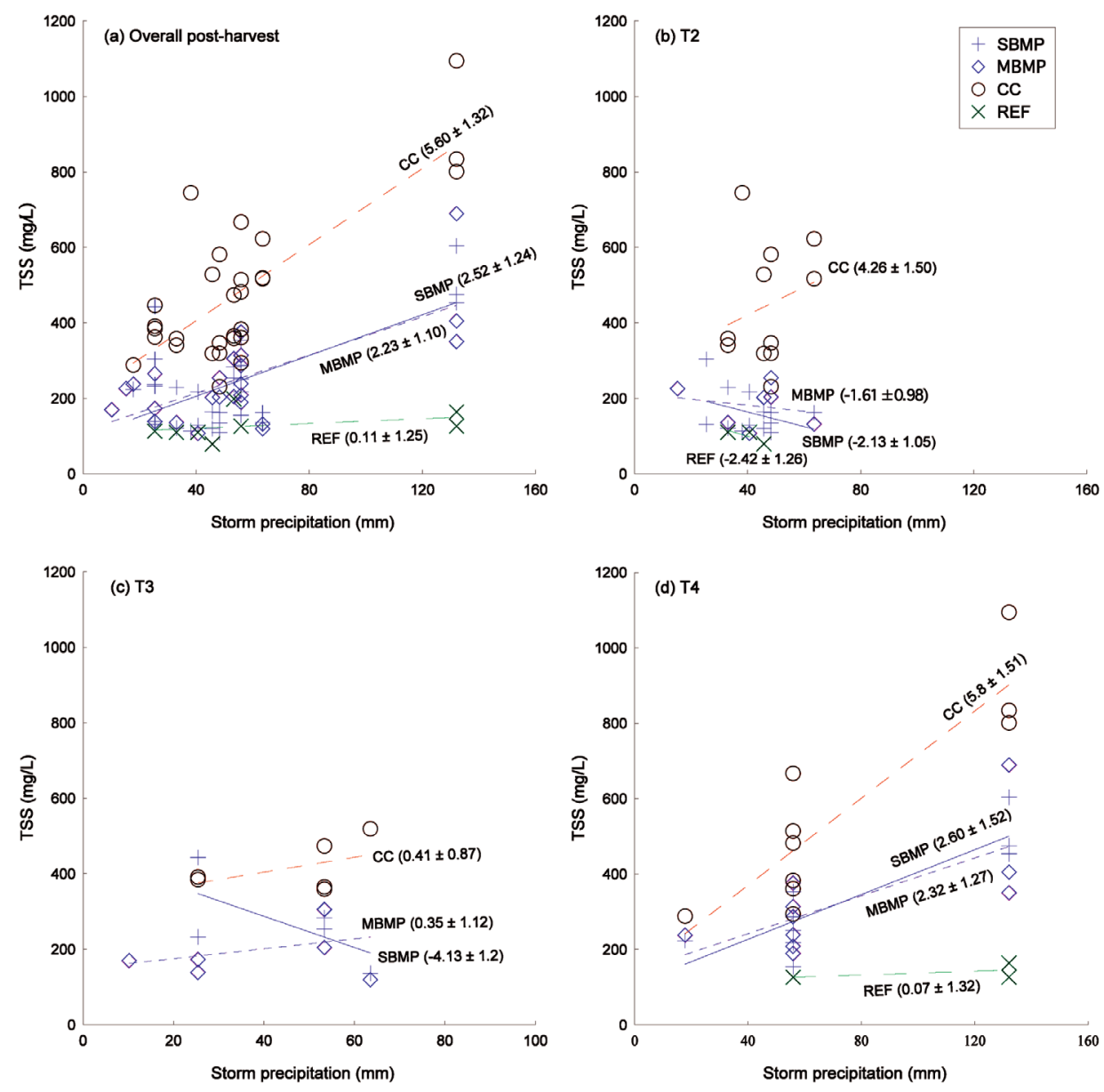

Fig. 6. Relationships between TSS and storm precipitation post-harvest among treatments in small headwater streams of Webster County, Mississippi. Data are not available for T1 and reference during T3 due to prolonged drought conditions and equipment malfunction. Values in parenthesis indicate $95 \%$ CI of the regression slope for each treatment during each time period. 


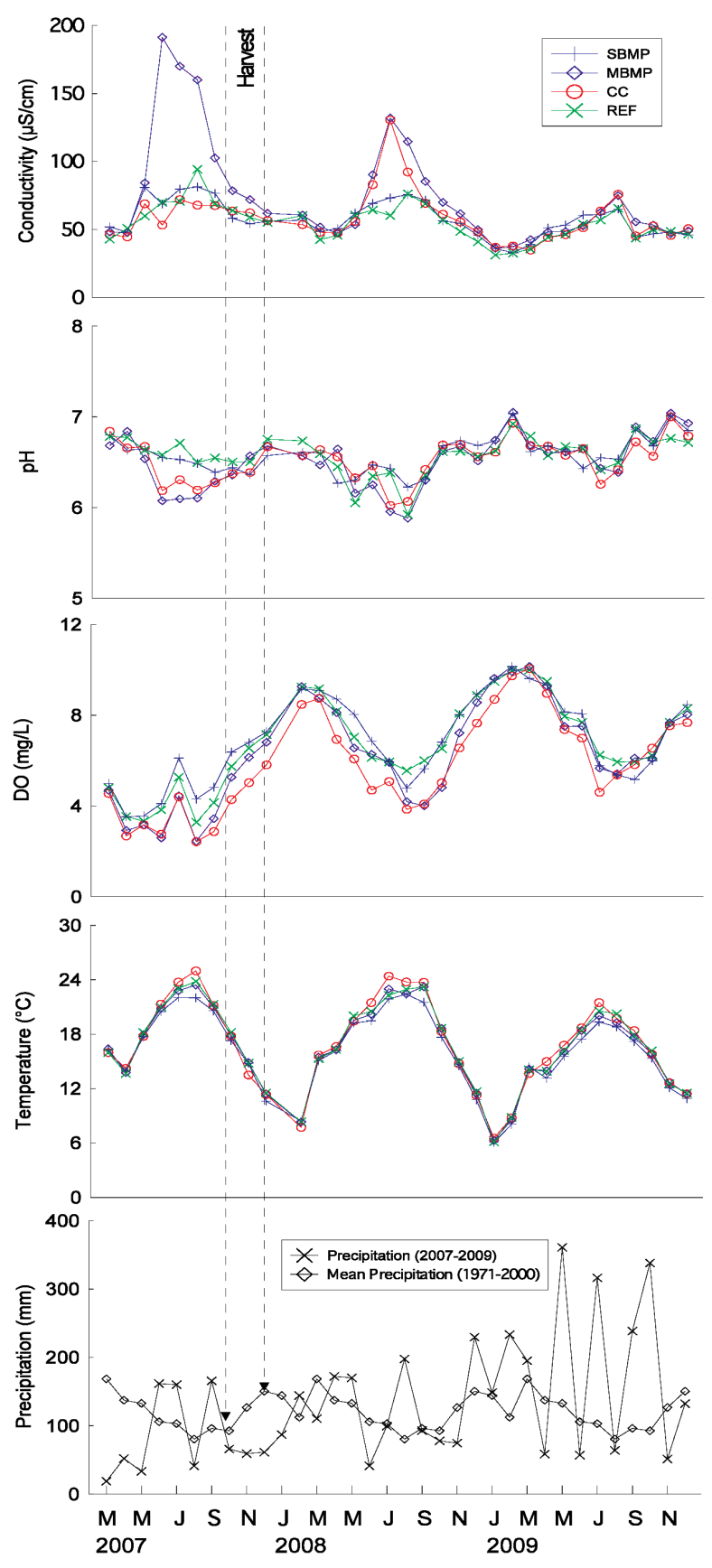

Fig. 7. Monthly treatment means of conductivity, pH, DO, and temperature in downstream reaches and monthly precipitation in small headwater streams of Webster County, Mississippi.

0.49). However, all treatments had similar values in water quality parameters during the remaining months. This was due to large variability in stream flow among watersheds associated with the summer drought conditions. Following harvest, downstream water quality did not change significantly, however, there was a significant but marginal difference $(p=0.044)$ in DO concentration among treatments during the summer (Fig. 7): $6.03 \mathrm{mg} / \mathrm{L}$ (SE: 0.29 in SBMP), $5.99 \mathrm{mg} / \mathrm{L}$ (SE: 0.32 in MBMP), $5.53 \mathrm{mg} / \mathrm{L}$ (SE: 0.39 in REF), and $5.28 \mathrm{mg} / \mathrm{L}$ (SE: 0.37 in CC). As expected, stream temperature was inversely related to DO concentration with strong seasonal patterns; relatively low temperature and high DO concentrations occurred during the winter and relatively high temperature and low DO concentrations occurred during the summer.

\section{DISCUSSTION}

Although a number of studies have reported timber harvesting effects on sediment yield and water quality in Southeastern U.S. (Beasley et al., 1986; Ursic, 1991, Wynn et al., 2000; Caroll et al., 2004; Houser et al., 2006), few studies have examined sediment mobility following harvest using direct measurement of erosion/ deposition in small watersheds. In the uppermost portions of study catchments, net erosion was the primary process in harvested treatments and hillslope positions across all treatments while net erosion/deposition within channel positions was widely variable among treatments. Net erosion/deposition patterns identified in the present study differ from studies in higher-order experimental watersheds of Mississippi. Keim and Schoenholtz (1999) reported that net deposition was dominant process in hillslope positions among treatments in a study of harvesting impacts on first-order perennial streams in the steep loessial bluff region of Mississippi. A similar result was observed by Carroll et al. (2004) in a study of effectiveness of SMZs on first- or second-order perennial streams in the Sand-Clay Hills of Mississippi. First-order perennial streams typically have lower channel and hillslope gradients than the uppermost portions (ephemeral streams) of headwater systems. They also have a larger storage capacity (e.g. wider floodplains) than ephemeral and intermittent streams, thus sediments transported through in-channel and external sources (e.g. bank erosion) during a flood ( $Q$ $>$ bankfull discharge) are often deposited in these downstream floodplains (Montgomery and Buffington, 1997).

There were differences in terms of harvested timber volume between SBMP and MBMP. MBMP had a greater basal area removal than SBMP. Unlike standard SBMP, logging debris was retained in ephemeral stream channels of MBMP during harvesting operations. This resulted in differences in operational implementation of harvest prescriptions between SBMP and MBMP such that logging crews were able to remove more timber due to reduced operational constraints (Choi et al., 2012). Stand heterogeneity may be another factor, in that selective cuts preferentially remove more timber where there is a concentration of high-value timber.

We hypothesized that MBMP would have reduced net soil erosion in both channel and hillslope positions in comparison to SBMP as a result of reduced energy for sediment transport. However, our expectations were not supported by results observed in channel positions. Channel aggradation and degradation is likely more affected by inherent channel conditions (e.g. watershed size, channel gradient, and channel morphology), than temporal and spatial changes due to logging debris in the channel system following harvest. Within the channel, there was a larger change in net erosion/deposition 
in harvested treatments than in REF. There was no significant difference in net erosion between two BMPs. This suggests logging debris did not significantly reduce streamflow and carrying capacity.

Clearcut sites typically have more logging debris than partial cut sites (Jackson et al., 2001; Carroll et al., 2004). Logging debris in clearcut sites may result in sediment storage or surface soil coverage. However, logging debris did not function as sediment storage or surface soil coverage in CC of this study indicating that logging slash left on the ground following intensive soil disturbance may not retain sediment efficiently (Fig. 5). This may be related to higher TSS in CC as compared to two BMPs. We also expected MBMP would have lower TSS than SBMP due to baffling effects of within-channel logging debris and reduced energy within the stream. MBMP did have consistently lower TSS than SBMP, but the difference was minor and not statistically significant. The CC was the highest level of disturbance on ephemeral-intermittent streams. Generally, TSS increases during or after harvest, but typically returns to values at or below pre-harvest conditions or reference level within two to three years following harvest (Kochenderfer et al., 1997; Macdonald et al., 2003; Gomi et al., 2005). Our results indicate that TSS in two BMPs returned to reference levels, but remained elevated above reference levels for the 22 months of monitoring after harvest in CC.

Understanding the linkages between hillslopes and channels in headwater streams is critical because the rate at which sediment is delivered to channels depends on the efficiency of the linkage (Gomi et al., 2005). The present study was hampered by limited water flux measurements in order to quantify sediment transported from headwater streams. While direct sediment transport to channels were not apparent in the erosion/deposition data, we observed that sediment produced from hillslopes was deposited near channel banks and intense storms often transported these sediments directly to drainage channels. There were some treatments which had concentrated flow areas directly connected to drainage channels through skid trails or hillslope ridges. Evidence of direct connections in sediment transport from hillslopes to drainage channels within erosion/deposition measurement transects was lacking due to dense vegetation and litter cover with the exception of CC where sediment was frequently transported through skid trails (e.g. sheet and rill erosion) and small hillslope failures. However, it is important to note that all harvested treatments were clearcut above the SMZ (outside erosion/deposition measurement transects) where there could be the possibility of tractors driving through the ephemeral streams. Ephemeral-intermittent streams in this study have dynamic patterns and a high magnitude of change in net erosion/deposition.

TSS concentrations tend to be more dependent on storm precipitation or precipitation intensity than instantaneous discharge (Nistor and Church, 2005; Karwan et al., 2007; Yuill and Gasparini, 2011). In the present study, we were limited by watershed characteristics and sampling equipment such that TSS sampling was conducted as a time-step function rather than a dischargestep function. Time-step based TSS sampling methods have drawbacks relative to other sampling methods because equal weight is given to each time interval (in this case 15 minutes) even though there may be a strong positive non-linear relationship between discharge and TSS load. When a time-step function is used, there is the potential for either underestimation of TSS as a result of dilution by lower discharge periods in the hydrograph, or overestimation of TSS as a result of high concentrations of sediment mobilized during the early stages of the hydrograph of ephemeral streams when discharge is still relatively low. These factors will tend to increase the variation around the actual mean thereby reducing our ability to detect differences in TSS caused by the treatments. The TSS load may have been altered by treatment induced changes to the hydrograph. However, we did not find any differences in storm discharge, peak discharge, or time of concentration (i.e. the steepness of the rising limb) in these ephemeral headwaters, so it is unlikely that TSS concentrations were greatly over or under estimated.

Results from this study suggest that there were generally good correlations between TSS and storm precipitation in all treatments across 26 months of the study (Fig. 6). However, post-harvest T2 to T3, relationships between TSS and storm precipitation were lacking and higher variability was probably due to a flushing effect of in-channel and external sources of sediment by the first few storm events immediately post-harvest (T1), infrequent storm events during a prolonged drought period (T2), and increased discharge resulting from drought recovery (T3). The study watersheds had the largest volume of storm precipitation and total precipitation during post-harvest T4 period (Fig. 6). This period showed drastically different responses compared to post-harvest T2 to T3. Higher availability of sediment as a result of constant sediment supply from harvested treatments was probably responsible for the significant linear relationships between TSS and storm precipitation during the largest storm event. We observed evidence of sediment transport from small slope failures, channel crossing areas, and skid trails in CC as well as destabilized logging debris in drainages and bank erosion in most harvested treatments following the storm event. However, caution should be exercised in making direct comparisons between net soil erosion/ deposition patterns (Fig. 5) and TSS (Fig. 6) due to lack of lateral connectivity.

The effects of timber harvesting on physical water characteristics are highly variable depending on climatic and topographic conditions (size, shape, elevation, slope, and soil type) of the watersheds, harvest intensity (clearcut vs. selective cutting), and land use change (Wegehenkel, 2003; Clinton and Vose, 2006). Keim and Schoenholtz (1999) and Carroll et al. (2004) found that timber harvesting did not significantly affect most water quality parameters during studies of harvesting impacts to first or second order headwater streams in Mississippi. 
In the present study, the results showed that timber harvesting did not significantly affect any of the measured water quality parameters with the exception of marginal differences among treatments in DO concentration during the summer. Such subtle changes in downstream water quality were primarily due to maintaining SMZs in all treatments including CC along downstream reaches of the perennial stream. It should be noted that timber harvesting in these areas was carried out in accordance with Mississippi's Forestry BMP guidelines. Ground disturbing activities were greatly reduced in SMZs as compared to other portions of treatments. Dodds and Oakes (2008) observed in a study of harvest impacts to headwater streams in eastern Kansas that water quality parameters sampled in downstream reaches were closely correlated with riparian cover adjacent to first-order streams. We found marginal differences among treatments in DO concentration during the summer. Even though we found a significant negative relationship between DO and temperature, lower DO concentrations as a result of clearcutting were not accompanied by an increase in stream temperature most likely due to increased contributions from groundwater. Groundwater is known to have lower DO concentrations than surface water during much of the year as a result of decomposition that occurs in the soil profile and higher DO concentrations during summer months as a result of high stream water temperatures (Malard and Hervant, 1999). In a previous study we demonstrated that the water table of the clearcut sites was significantly elevated as a result of the loss of evapotranspiring surfaces (Choi et al., 2012). An elevated water table will contribute more water to base flow thereby driving stream DO levels down during summer months when streams receive little input from oxygenated precipitation. The results of our study suggest that the effects of increased insolation due to overstory removal on water temperature may be mitigated by the influx of cooler groundwater; however the effects of the drought that occurred at study initiation may have increased the variability of watershed response, thereby limiting the strength of this conclusion.

\section{CONCLUSIONS}

This study tested treatments for ephemeral-intermittent streams in the Upper Gulf Coastal Plain of Mississippi, USA. We found that forest clearcutting with no BMPs involving intensive surface soil and forest floor disturbance resulted in substantial impacts to net erosion/deposition in both channel and hillslope positions and significantly increased TSS following harvest. Clearcutting with no regard for management of ephemeral stream channels appears to have increased the flux of sediment to downstream stream reaches. These impacts were ameliorated by implementing two BMPs during harvesting activities. These findings support the use of either BMP treatments for ephemeral-intermittent streams. Logging debris left in the channel of MBMP did not cover enough soil surface to reduce ero- sion and sediment flux; however, MBMP may be more economically beneficial since more timber can be harvested due to reduced operational constraints.

\section{ACKNOWLEDGEMENT}

Funding for this project was provided by USDA Forest Service, Southern Research Station, Center for Bottomland Hardwoods Research, Stoneville, MS under joint venture agreement (06-JV-11330127-186), Weyerhaeuser NR Company, and the National Council for Air and Stream Improvement, Inc. We thank Ricky Hegwood, retired, Weyerhaeuser NR Company for his assistance in selecting study sites.

\section{REFERENCES}

American Public Health Association 1987 Standard methods for the examination of water and wastewater.

Baillie B. R, K. J. Collier and J. Nagels 2005 Effects of forest harvesting and woody debris removal on two Northland streams, New Zealand. New Zealand Journal of Marine and Freshwater Research, 39: 1-15

Bailey R. G. 1983 Delineation of ecosystem regions. Environmental Management, 7: 365-373

Beasley R. S., A. B. Granillo and V. Zillmer 1986 Sediment losses from forest management: Mechanical versus chemical site preparation after clear cutting. Journal of Environmental Quality, 15: 413-416

Benda L. E., M. A. Hassan, M. Church and C. L. May 2005 Geomorphology of steepland headwaters: the transition from hillslopes to channels. Journal of American Water Resources Association, 41: 835-851

Blackburn W. H., R. W. Knight, J. C. Wood and A. H. Pearson 1990 Stormflow and sediment loss from intensively managed forest watersheds in east Texas. Water Resources Bulletin, 26: 465477

Blinn C. R. and M. A. Kilgore 2001 Riparian management practices: a summary of state guideline. Journal of Forestry, 4:187-201

Carroll, G. D., S. H. Schoenholtz, B. W. Young and E. D. Dibble 2004. Effectiveness of forestry streamside management zones in the sandy-clay hills of Mississippi: early indications. Water, Air and Soil Pollution, 4: 275-296

Choi B. 2011 Headwater hydrologic functions in the Upper Gulf Coastal Plain of Mississippi. Ph.D Dissertation, Mississippi State University, Forestry Department, pp. 115

Choi B., J. C. Dewey, J. A. Hatten, A. W. Ezell and Z. Fan 2012 Changes in vegetative communities and water table dynamics following timber harvesting in small headwater streams. Forest Ecology and Management, 281: 1-11

Clinton B. D. and J. M. Vose 2006 Variation in Stream Water Quality in an Urban Headwater Stream in the Southern Appalachians. Water, Air and Soil Pollution, 169: 331-353

Collier K. J. and E. J. Bowman 2003 Role of wood in pumice-bed streams I: Impacts of post-harvest management on water quality, habitat and benthic invertebrates. Forest Ecology and Management, 177: 243-259

Diez J. R., A. Elosegi and J. Pozo 2001 Woody debris in North Iberian streams; Influence of geomorphology, vegetation, and management. Environmental Management, 28: 687-698 
Dodds W. K. 2008 Oakes RM. Headwater influences on downstream water quality. Environmental Management, 41: 367377

Doppelt B., M. Scurlock, C. Frissell and J. Karr 1993 Entering the Watershed. Island Press, Washington, D.C.

Fritz K. M., B. R. Johnson and D. M. Walters 2008 Environmental indicators of hydrologic permanence in forested headwater streams, Journal of North American Benthological Society, 27: 690-704

Gomi T., R. C. Sidle and J.S. Richardson 2002 Understanding processes and downstream linkages of headwater systems. BioScience, 52: 905-916

Gomi T., R. C. Sidle, S. Noguchi, J. N. Negishi and N. Abdul Rahim 2006 Sediment, wood, and detritus accumulations in tropical headwater streams: effects of logging and riparian management. Forest Ecology and Management, 224: 166-175

Gomi T., R. D. Moore and M. A. Hassan 2005 Suspended sediment dynamics in small forest streams of the Pacific Northwest. Journal of American Water Resources Association, 41: 877898

Grace J. M. 2005 Forest operations and water quality in the south. Transaction of the ASABE, 48: 871-880

Hansen W. F. 2001 Identifying stream types and management implications. Forest Ecology and Management, 143: 39-46

Heartstill-Scalley T. and T. M. Aid 2003 Riparian vegetation and stream condition in a tropical agriculture-secondary forest mosaic. Ecological Application, 13: 225-234

Holland J. M. and M. L. Luff 2000 The effects of agricultural practices on Carabidae in temperate agroecosystems. Integrated Pest Management Review, 5: 109-129

Houser J. N., P. J. Mulholland and K.O. Maloney 2006 Upland disturbance affects headwater stream nutrients and suspended sediments during baseflow and stormflow. Journal of Environmental Quality, 35: 352-365

Ice G. G., W. F. Megahan, M. W. McBroom and T. M. Williams 2003 Opportunities to assess past, current, and future impacts from forest management. Proceedings of Total Maximum Daily Load (TMDL) Environmental Regulations II, Albuquerque, New Mexico

Jackson C. R., C.A. Sturm and J. M. Ward 2001 Timber harvest impacts on small headwater stream channels in the Coast Ranges of Washington. Joumal of American Water Resources Association, 37: 1533-1549

Karwan D. L., Gravelle J. A. and J. A. Hubbart 2007 Effects of timber harvest on suspended sediment loads in Mica Creek, Idaho. Forest Science, 53: 181-188

Keim R. F. and S. H. Schoenholtz 1999 Functions and effectiveness of silvicultural streamside management zones in loessial bluff forests. Forest Ecology and Management, 118: 197-209

Kochenderfer J. N., P. J. Edwards and F. Wood 1997 Hydrologic impacts of logging an Appalachian watershed using West Virginia's best management practices. Northern Journal of Applied Forestry, 14: 207-218

Leopold L. B., M. G. Wolman, J. P. Miller 1964 Fluvial processes in geomorphology. Dover Publication, New York

Lynch J. A., E. S. Corbett and K. Mussallem 1985 Best management practices for controlling non-point source pollution on forested watersheds. Journal of Soil and Water Conservation, 40: 164-167

Macdonald J. S., P. Beaudry, E. A. Maclsaac and H. E. Herunter
2003 The effects of forest harvesting and best management practices on streamflow and suspended sediment concentration during snowmelt in headwater streams in sub-boreal forest of British Columbia, Canada. Canadian Journal Forest Research, 33: 1397-1407

MacDonald L. H. and D. B. Coe 2007 Influence of headwater streams on downstream reaches in forested areas. Forest Science, 53: 148-168

Malard F. and F. Hervant 1999 Oxygen supply and the adaptations of animals in groundwater. Freshwater Biology, 41: 1-30

McMullen J. W. and J. G. Ford 1978 Soil survey of Webster County, Mississippi. USDA Soil Conservation Service. In cooperation with the Mississippi Agricultural and Forestry Experiment Station, p. 99

Meyer J. L. and J. B. Wallace 2001 Lost linkages and lotic ecology: rediscovering small streams. In: Press, M. C., N. J. Huntley, S. Levin editors. Ecology: Achievement and Challenges. Blackwell Scientific, Oxford, UK, pp. 295-317

Mississippi Forestry Commission 2000 Best Management Practices for Forestry in Mississippi. MFC Publication, p. 107

Montgomery D. R. and J. M. Buffington 1997 Channel-reach morphology in mountain drainage basins. Geological Society of America Bulletin, 109: 596-611

Muotka T. and R. Virtanen 1995 The stream as a habitat templet for bryophytes: species' distributions along gradients in disturbance and substratum heterogeneity. Freshwater Biology, 33: 141-160

Muys B. and P. Granval 1997 Earthworms as bio-indicators of forest site quality. Soil Biology and Biochemistry, 29: 323-328

National Drought Mitigation Center 2010 Drought monitor archives. http://drought.unl.edu/dm/archive.html [Accessed 3 February 2010]

Nistor C. J. and M. Church 2005 Suspended sediment transport regime in a debris-flow gully on Vancouver island, British Columbia. Hydrological Processes, 19: 861-885

Naiman R. J. and H. Décamp 1997 The ecology of interfaces: riparian zones. Annual Review Ecology, Evolution and Systematics, 28: 621-658

Paoletti M. G. 1999 The role of earthworms for assessment of sustainability and as bioindicators. Agriculture, Ecosystems and Environments, 74: 137-155

Rivenbark B. L. and C. R. Jackson 2004 Concentrated flow breakthroughs moving through silvicultural streamside management zones: southeastern Piedmont, USA. Journal American Water Resources Association, 40: 1043-1052

SAS Institute Inc. 2008 SAS/STAT 9.2 User's Guide. SAS Institute Inc., Cary, NC, USA

Sidle R. C., S. Sasaki, M. Otsuki, S. Noguchi and N. Abdul Rahim 2004 Sediment pathways in a tropical forest: effects of logging roads and skidtrails. Hydrological Processes, 18: 703-720

Sun G., S. G. McNulty, J. P. Shepard, D. M. Amatya, H. Riekerk and N. B. Comeford 2001 Effects of timber management on the hydrology of wetland forests in the southern United States. Forest Ecology and Management, 143: 227-236

Ursic S. J. 1997 Hydrologic effects of clearcutting and stripcutting loblolly pine in the coastal plain. Water Resources Bulletin, 27: 925-937

Vowell J. L. and R. B. Frydenborg 2004 A biological assessment of best management practice effectiveness during intensive silviculture and forest chemical application. Water, Air and Soil 
Pollution, 167: 297-307

Wegehenkel M. 2003 Longterm evaluation of land use changes on catchment water balance: a case study from North-East Germany. Physics and Chemistry of the Earth, 28: 12811290

Wenger S. 1999 A review of the scientific literature on riparian buffer width, extent and vegetation. University of Georgia, Institute of Ecology, Office of Public Service and Outreach. Athens, GA, USA, p. 59

Wipfli M. S., J. S. Richardson and R. J. Naiman $2007 \quad$ Ecological linkages between headwaters and downstream ecosystems: Transport of organic matter, invertebrates, and wood down headwater channels. Journal American Water Resources
Association, 43: 72-85

Wynn T. M., S. Mostaghimi, J. W. Frazee, P. W. McClellan, R. M. Shaffer and W. M. Aust 2000 Effects of forest harvesting best management practices on surface water quality in the Virginia coastal plain. Transaction of the ASABE, 43: 927-936

Woodsmith R. D. and F. J. Swanson 1997 The influence of large woody debris on forest stream geomorphology. In: Proceedings of Management of Landscape Disturbed by Channel Incision. Wang SSY, Langedoen EJ, Shields FD editors. University of Mississippi, Oxford, MS, pp. 133-138

Yuill B. T. and N. M. Gasparini 2011 Hydrologic controls on wash load sediment concentrations within a low-ordered, ephemeral watershed. Journal of Hydrology, 410: 73-83 